\title{
INFECCIÓN MIXTA DE Barley stripe mosaic virus Y DEL VIRUS DEL MAL DE RÍO CUARTO EN CEBADA EN ARGENTINA
}

\author{
JOEL D. ARNEODO* \& GRACIELA A. TRUOL \\ Instituto de Fitopatología y Fisiología Vegetal (IFFIVE) - INTA, Camino 60 Cuadras km 5 1⁄2, CP 5119, Córdoba, \\ Argentina, fax (0351) 4974330, e-mail: gtruol@correo.inta.gov.ar
}

(Aceptado para publicación el 21/03/2001)

Autor para correspondencia: Graciela A. Truol

\section{ABSTRACT \\ Mixed infection by Barley stripe mosaic virus and "mal de Río Cuarto virus" on barley in Argentina}

A double infection produced by Barley stripe mosaic virus (BSMV), genus Hordeivirus, and the "mal de Río Cuarto virus" (MRCV), genus Fijivirus, was demonstrated for the first time on barley crops (Hordeum vulgare) in Argentina. Identification of these viruses was made by symptomatology, serology and electron microscopy.
El Barley stripe mosaic virus (BSMV), género Hordeivirus, fue detectado en Argentina a fines de la década del '70, sobre cultivos de trigo (Triticum aestivum L.) y cebada (Hordeum vulgare L.) en la provincia de Córdoba (Zumelzu \& Docampo, RIA - INTA, 15: 439. 1980). Esa misma jurisdicción corresponde a la zona endémica del virus del "mal de Río Cuarto" (MRCV), cuya etiología fue establecida por Nome et al. (Phytopathol. Z., 101:7-15. 1981) al observar al microscopio electrónico en cortes ultrafinos partículas semejantes a reovirus. El MRCV posee un amplio rango de hospedantes, dentro de la familia Poaceae, entre los que se incluye la cebada.

Desde el año 1996 se han advertido, en la provincia de Córdoba, plantas de cebada con una apariencia que no respondía totalmente a los síntomas individuales de las virosis antes mencionadas. Éstas se destacaban por su aspecto achaparrado, con hojas recortadas y retorcidas en tirabuzón (propio del MRCV), junto a un mosaico estriado típico del BSMV. A fin de determinar la etiología de esta severa sintomatología, se colectaron muestras para la realización de estudios serológicos y microscópicos. Los primeros fueron efectuados con antisueros anti MRCV (DAS - ELISA) y anti BSMV (ELISA indirecta) en distintas porciones de una misma hoja, obteniéndose resultados positivos con los dos virus. En cuanto a la microscopía electrónica, la observación de cortes ultrafinos de la lámina foliar permitió detectar partículas semejantes a BSMV en el mesófilo y tejido floemático, mientras que viriones sueltos similares a MRCV y viroplasmas característicos de los fijivirus fueron detectados en el floema y células acompañantes (Figura 1). Frecuentemente se

\footnotetext{
* Becario de CONICET
}

visualizaron, dentro del tejido floemático, partículas virales de ambos tipos en el citoplasma de la misma célula. Se presenta de este modo evidencia de la asociación entre estas dos virosis, y los efectos que causan sobre las plantas de cebada.

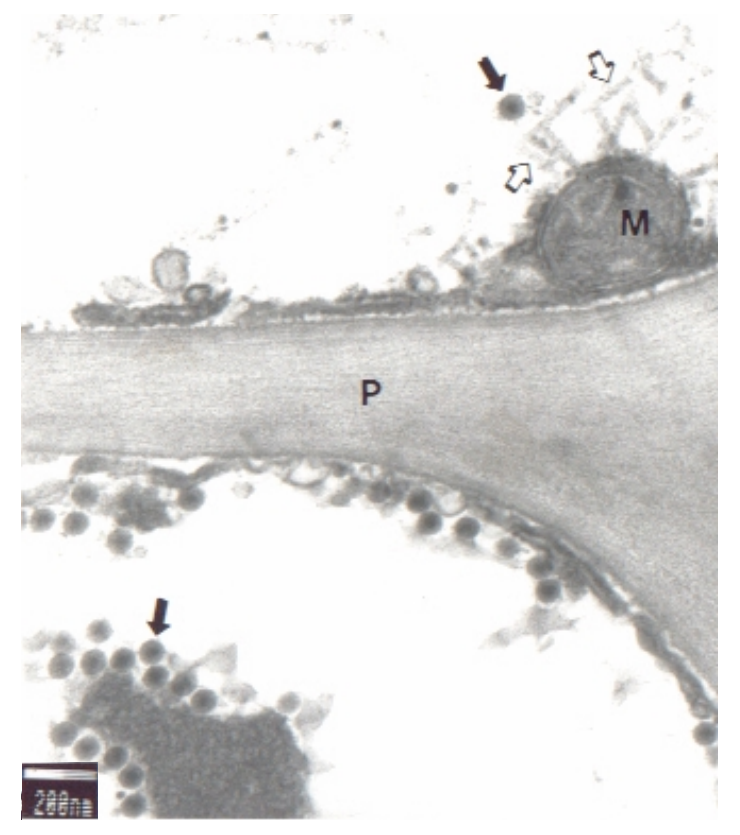

FIG. 1 - Partículas de Barley stripe mosaic virus (flechas vacías) y del virus del mal de Río Cuarto (flechas rellenas) en células del tejido floemático en cebada (Hordeum vulgare). P: pared celular. M: mitocondria. 